\title{
Curcumin Inhibit PhIP-Induced Carcinogenicity by Regulating Expression of Nrf2 and FOXO Targets, and BRCA-1 and P16 Expression in Breast Epithelial Cells
}

Ashok Jain*

Department of Natural and Forensic Sciences, Albany State University, Albany GA 31705, USA

"Corresponding author: Ashok Jain, Department of Natural and Forensic Sciences, Albany State University, Albany GA 31705, USA, Tel: 001-229-430-4817; Fax: 001-229-639-3702; E-mail: ashok.jain@asurams.edu

Rec date: July 23, 2015; Acc date: Aug 18, 2015; Pub date: Aug 20, 2015

Copyright: @ 2015 Jain A, et al. This is an open-access article distributed under the terms of the Creative Commons Attribution License, which permits unrestricted use, distribution, and reproduction in any medium, provided the original author and source are credited.

\section{Brief Report}

PhIP (Amino-1-methyl-6-phenylimidazo[4,5-b]pyridine) is a heterocyclic amine (HCA) which is formed when meat products are cooked at high temperature. PhIP is known for its genotoxic and carcinogenic effects causing several types of cancer, including breast cancer. HCA causes multifold cytotoxic effect, for example metabolism of PhIP leads to ROS production, and PhIP metabolites produce DNA adduct and DNA strand breaks [1-4]. Breast epithelial cells contain all the machinery to metabolize HCA and the genotoxic effects of these metabolites may lead to breast cancer [1].

The prevention of cancer through diet is categorized as one of the most effective ways to reduce cancer incidence [5]. We hypothesized that curcumin may be a potential food additive that may be inhibitory to $\mathrm{PhIP}$-induced carcinogenicity by inhibiting ROS production, DNA adduct formation and DNA strand breaks. We developed a model system using the breast epithelial cells (MCF-10A) to screen several dietary additives to identify phytochemical that is capable to inhibit PhIP cytotoxicity. Curcumin a polyphenol and major component of the Indian spice turmeric, which is used in various food preparations, is known to inhibit cell proliferation and has anticancer effects [6]. In this brief report, we describe how curcumin inhibits PhIP-induced ROS production, DNA adduct formation and DNA damage in MCF-10A cells.

MCF-10A human breast epithelial cells were cultured in a humidified incubator at $37^{\circ} \mathrm{C}$ under $5 \% \mathrm{CO}_{2}$ atmospheric conditions in RPMI media supplemented with $10 \mu \mathrm{g} / \mathrm{ml}$ insulin, $20 \mathrm{ng} / \mathrm{ml}$ epidermal growth factor, $10 \mathrm{mg} / \mathrm{ml}$ hydrocortisone, $5 \%$ horse serum and $1 \%$ penicillin-streptomycin $(10,000 \mathrm{U} / \mathrm{ml})$. Cells were treated with or without $\mathrm{PhIP}(50$ and $250 \mu \mathrm{M})$ in the presence or absence of curcumin $(150 \mu \mathrm{M})$ and cell viability determined using the cell counting kit-8 (Dojindo Laboratories). Cells were pretreated with curcumin 15 minutes prior to dosing with PhIP (50 or $250 \mu \mathrm{M}$ ). MCF $10 \mathrm{~A}$ cells viability is decreased when treated with $\mathrm{PhIP}$ in a dose dependent manner. Results shows that curcumin at a concentration of $150 \mu \mathrm{M}$ significantly inhibited PhIP-induced reductions in viability at $24 \mathrm{~h}$, with cells treated with $50 \mu \mathrm{M}$ PhIP plus $150 \mu \mathrm{M}$ curcumin, and $250 \mu \mathrm{M}$ PhIP plus $150 \mu \mathrm{M}$ curcumin (Table 1a).

The antioxidant capacity of curcumin was analyzed in the absence and in the presence of the PhIP, a well-known peroxidant agent. Its efficiency was evaluated in terms of inhibition of intracellular reactive oxygen species (ROS) production induced spontaneously or in the presence of PhIP. Intracellular free radical species were detected by measuring the fluorescence intensity values (using a Biotek, Synergy HT instrument with an excitation 475-495 and emission 518-528) due to the oxidation of DCF and expressed as relative fluorescence units (RFU).

In the absence of PhIP, ROS production was limited but increased significantly in the presence of PhIP in a dose-dependent manner. Cotreatment of MCF-10A cells with curcumin resulted in a significant decrease in PhIP-induced ROS production (Table 1b).

\begin{tabular}{|c|c|}
\hline (a) Cell Viability (\%) & Mean \\
\hline Control & 100 \\
\hline PhIP 50 mM & 80 \\
\hline PhIP $50 \mathrm{mM}+$ Cur $25 \mathrm{mM}$ & 78 \\
\hline PhIP $50 \mathrm{mM}+$ Cur $50 \mathrm{mM}$ & 81 \\
\hline PhIP $50 \mathrm{mM}+$ Cur $75 \mathrm{mM}$ & $92^{*}$ \\
\hline PhIP $50 \mathrm{mM}+$ Cur $100 \mathrm{mM}$ & $97^{* * *}$ \\
\hline PhIP $50 \mathrm{mM}+$ Cur $150 \mathrm{mM}$ & $101^{\star \star *}$ \\
\hline PhIP $50 \mathrm{mM}+$ Cur $200 \mathrm{mM}$ & 81 \\
\hline PhIP $250 \mathrm{mM}$ & 33 \\
\hline PhIP $250 \mathrm{mM}+$ Cur $25 \mathrm{mM}$ & $49^{*}$ \\
\hline PhIP $250 \mathrm{mM}+$ Cur $50 \mathrm{mM}$ & $69^{* \star *}$ \\
\hline PhIP $250 \mathrm{mM}+$ Cur $75 \mathrm{mM}$ & $74^{* * *}$ \\
\hline PhIP 250 mM+Cur 100 mM & $86^{* * *}$ \\
\hline PhIP $250 \mathrm{mM}+$ Cur $150 \mathrm{mM}$ & $97^{* * *}$ \\
\hline PhIP $250 \mathrm{mM}+$ Cur $200 \mathrm{mM}$ & $66^{\star * *}$ \\
\hline \multicolumn{2}{|c|}{ (b) ROS Activation (Mean Relative Fluorescence Units) } \\
\hline Control & 3.33 \\
\hline PhIP $50 \mathrm{mM}$ & $6.33^{* * *}$ \\
\hline PhIP 250 mM & $8.33^{* \star *}$ \\
\hline PhIP $50 \mathrm{mM}+$ Cur $150 \mathrm{mM}$ & $3.33^{* * *}$ \\
\hline PhIP $250 \mathrm{mM}+$ Cur $150 \mathrm{mM}$ & $2.66^{* * *}$ \\
\hline Cur $150 \mathrm{mM}$ & 2 \\
\hline $\mathrm{H} 2 \mathrm{O} 21 \mathrm{mM}$ & 5 \\
\hline $\mathrm{H} 2 \mathrm{O} 210 \mathrm{mM}$ & 10.6 \\
\hline
\end{tabular}




\section{(c) Comet Assay (Mean Olive Tail Moment)}

\begin{tabular}{|l|l|}
\hline Control & 0.155 \\
\hline PhIP $50 \mu \mathrm{M}$ & $1.02^{\star \star *}$ \\
\hline PhIP $250 \mu \mathrm{M}$ & $1.5^{\star \star *}$ \\
\hline PhIP $50 \mu \mathrm{M}+\mathrm{Cu} 150 \mu \mathrm{M}$ & $0.26^{\star \star *}$ \\
\hline PhIP250 $\mu \mathrm{M}+\mathrm{Cu} 150 \mu \mathrm{M}$ & $0.53^{\star \star *}$ \\
\hline Cu $150 \mu \mathrm{M}$ & 0.17
\end{tabular}

(a) Cell viability with various doses of curcumin co-treated with $50 \mu \mathrm{M}$ and 250 $\mu \mathrm{M}$ PhIP. All doses of curcumin produced reversal of PhIP-induced cytotoxicity but curcumin at $150 \mu \mathrm{M}$ exhibited the greatest degree of reversal of cytotoxicity. Line shows significance compared to PhIP treated samples.

(b) Quantitative fluorescence intensity analysis of ROS production in PhIPtreated MCF-10A cells upon co-treatment with curcumin. MCF-10A cells were treated with or without PhIP in the presence and absence of curcumin for 24 hours and then fluorescence intensity was measured with DCF-DA $(5 \mu \mathrm{g})$ within 45 minutes. Co-treatment with curcumin reduced the PhIP-stimulated ROS production in MCF-10A cells

(c) Inhibition of PhIP-induced DNA strand breaks by curcumin at $24 \mathrm{~h}$. MCF $10 \mathrm{~A}$ cells were treated and analyzed to score comet tail moment using comet analysis system (Loats Associate System, Westminster, MD). Values are mean from three independent experiments performed in triplicate. The statistical significance is expressed as ${ }^{*} p<0.05,{ }^{* *} p<0.01$, and ${ }^{* * *} p<0.001$.

Table 1: Effect of curcumin on inhibition of PhIP induced carcinogenicity.

DNA adduct formation was determined using an immunofluorescence method with an anti-DNA adduct primary antibody [8]. DNA adducts accumulated in a dose-dependent manner in both 50 and $250 \mu \mathrm{M}$ PhIP-treated breast epithelial MCF 10A cells. When MCF 10A cells were co-treated with curcumin, PhIP-induced DNA adduct formation was noticeably reduced [7].

The ability of curcumin to inhibit PhIP-induced DNA double strand breaks in MCF-10A cells was then determined using the comet assay and measuring the olive tail moment. Treatment with curcumin $(150 \mu \mathrm{M})$ had no effect on the production of DNA strand breaks compared to the controls. However, pretreatment with curcumin inhibited DNA double strand breaks induced by PhIP after $24 \mathrm{~h}$ (Table 1c). These results also support the DNA adduct data since the reduction in DNA adduct formation in the presence of curcumin represents decreased DNA damage.

To understand the interaction of PhIP and curcumin at the molecular level reverse transcriptase PCR (RT-PCR) was performed. Oxidative stress signals through NRF-2 [Nuclear factor (erythroidderived 2)-like 2] and its targets such as NQO-1 [NAD(P)H quionine oxidoreductase-1], GPX-1 [glutathione peroxidase] and GSR [glutathione reductase], as well as FOXO [forkhead box protein] targets such as CAT [catalase], GADD-45 [growth arrest and DNA damage-inducible 45] and PRDX-3 [Thioredoxin-dependent peroxide reductase], and the expression of these genes was monitored. H2AX [histone $\mathrm{H} 2 \mathrm{~A}$ ], BRCA-1 [breast cancer 1, early onset] and P-16 (cyclin-dependent kinase inhibitor 2A) were also evaluated. PhIP induces the expression of NQO1, GPX-1, GSR, Catalase, GADD45, PRDX-3, BRCA-1 and H2AFX. However, curcumin inhibited the PhIP-elevated expression of these genes. Whereas the expression of cyclin-dependent kinase inhibitor 2A (P16), which is also known as multiple tumor suppressor protein, is suppressed by $\mathrm{PhIP}$ as compared to control; however, P16 expression was maintained in breast epithelial cells co-treated with curcumin. Since MCF-10A cells are P53 deficient, the expression of the P16 tumor suppressor is important to reduce PhIP carcinogenicity. Thus, down-regulation of the P16 transcript by PhIP could result in a carcinogenic effect, such that maintenance of P16 expression by curcumin suggests that this agent should reduce PhIP-induced carcinogenicity. The house-keeping gene hypoxanthine phosphoribosyl transferase (HPRT) was expressed uniformly in all groups (Figure 1).

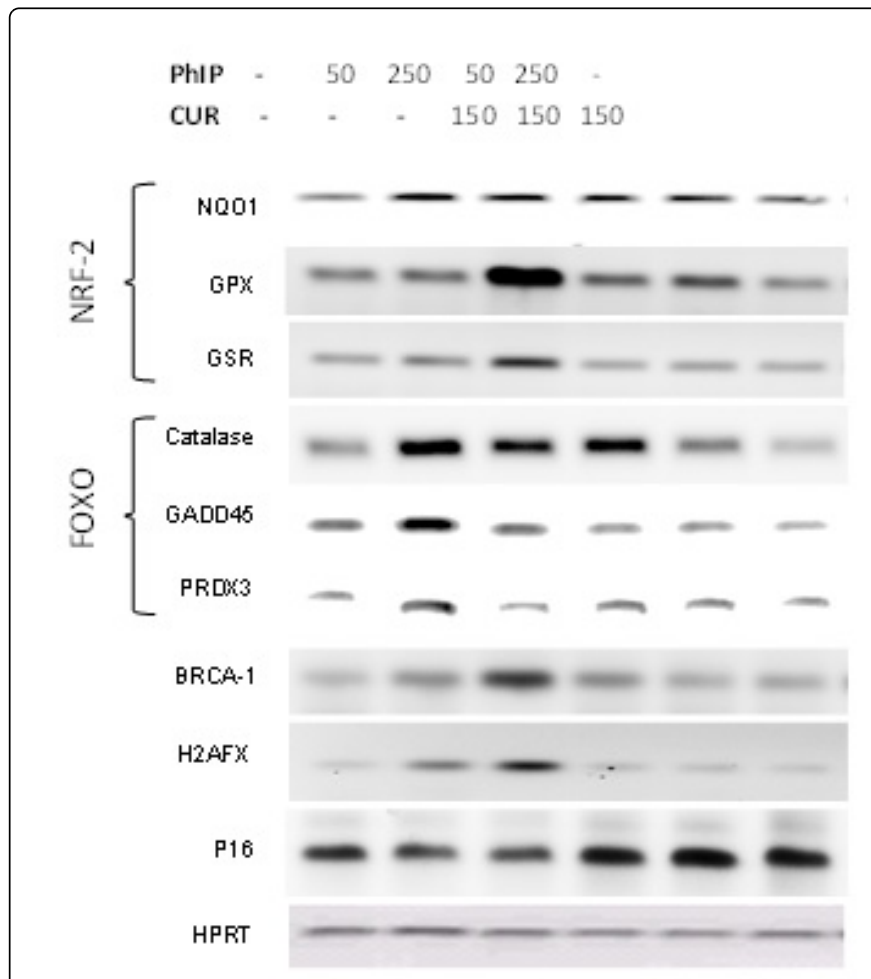

Figure 1: Effect of PhIP and curcumin alone and in combination on Nrf2, FOXO, BRCA-1, H2AFX and P16 signaling pathways, with HPRT used as a normalization control. MCF 10A cells were treated for $24 \mathrm{~h}$, total RNA was isolated and RT-PCR was applied to amplify specific gene products. The sequences of forward and reverse primers are given in Table 2. Comparative band intensity was used to determine the induction or suppression of each transcript. All results were repeated at least twice with similar expression

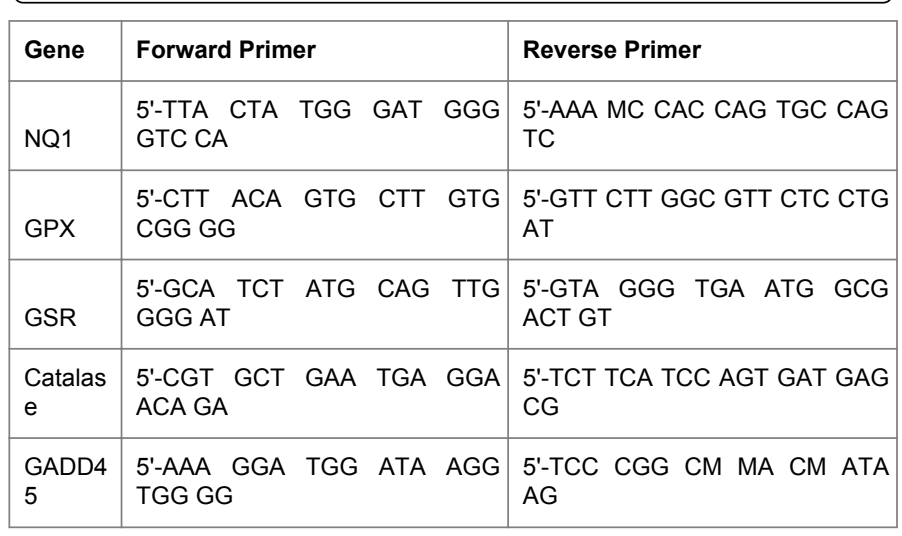




\begin{tabular}{|l|l|l|}
\hline PRDX3 & $\begin{array}{l}\text { 5'-TCT GGT TCC AGT CAA GCA } \\
\text { AA }\end{array}$ & $\begin{array}{l}\text { 5'-CGT AGT CTC GGG AM TCT } \\
\text { GC }\end{array}$ \\
\hline BRCA1 & $\begin{array}{l}5^{\prime}- \\
\text { TTGCGGGAGGAAAATGGGTAG } \\
\text { TTA }\end{array}$ & $\begin{array}{l}5^{\prime}- \\
\text { TGTGCCAAGGGTGAATGATGA } \\
\text { AAG }\end{array}$ \\
\hline H2AFX & $\begin{array}{l}5^{\prime}- \\
\text { TTGCCCCGCAGTCTGAAGCG }\end{array}$ & $\begin{array}{l}5^{\prime}- \\
\text { CCGGCMGAAGGCCACCCAGG }\end{array}$ \\
\hline P16 & $\begin{array}{l}5^{\prime}- \\
\text { GTGTGGCACATCCCGCCCTC }\end{array}$ & $\begin{array}{l}\text { 5'- } \\
\text { CGCAAGCTGGCTGGCTCACT }\end{array}$ \\
\hline HPRT & $\begin{array}{l}\text { 5'- } \\
\text { GCGTCGTGATTAGCGATGATG }\end{array}$ & $\begin{array}{l}\text { 5'- } \\
\text { CCTCCCATCTCCTTCATGACAT } \\
\text { CT }\end{array}$ \\
\hline
\end{tabular}

Table 2: Primers sequence used in RT PCR.

Breast cancer is one of the leading causes of death in women $[9,10]$, and diet plays a major role in development of the disease [5]. A direct relationship between red meat consumption and the PhIP associated development of breast cancer has been demonstrated [11]. This is the first study demonstrating the mechanism by which curcumin can inhibit the carcinogenic effect of PhIP in MCF-10A breast epithelial cells. Normal breast epithelial cells have an inherent capacity to bioactivate PhIP which then causes DNA damage. Our cytotoxicity data reveals that curcumin can inhibit PhIP-induced cell death. Bioactivated PhIP also causes the production of ROS; the effect of PhIP on both these processes has been established previously [12]. PhIPinduced DNA adducts and ROS lead to DNA double strand breaks [7]. The cumulative effect of these factors affects cells' normal behavior and is responsible for the decrease in cell viability. Many studies demonstrate that an imbalance in the production and detoxification of ROS may lead to various cancers $[13,14]$. Our results show that curcumin reduced DNA adduct formation, decreased DNA double strand breaks and reduced ROS production to basal levels to result in an inhibition of PhIP-induced cell death [7]. Although PhIP induces antioxidant and DNA repair mechanisms through the Nrf2 and FOXO pathways, this response does not completely inhibit ROS or DNA adduct formation. Curcumin, however, inhibits both ROS and DNA adduct generation to rescue DNA damage. We conclude that in addition to DNA adduct formation, oxidative DNA damage is crucial to PhIP-induced carcinogenicity. Previously, Sato et al., [15] have shown that ROS production during the metabolism of heterocyclic amines including PhIP occurs through NADPH/P450, suggesting that production of ROS in PhIP-treated MCF-10A cells is due to the metabolism of PhIP to N-hydroxy-PhIP through p450 detoxification. Therefore, DNA double strand breaks in PhIP-treated cells are likely to arise through two mechanisms: (i) the ROS generated directly contribute to DSB; and (ii) PhIP-DNA adduct formation leads to DNA strand breaks [7].

Our results clearly show that many antioxidant genes are induced in the presence of PhIP. Both the Nrf2 and FOXO pathways are upregulated by PhIP to scavenge the elevated ROS and protect cells from DNA adduct formation and the resulting DNA damage. Increased expression of H2AFX and BRCA-1 in the PhIP-treated group as well as data from comet assays, ROS monitoring and immunofluorescence with anti-DNA adduct antibodies support this idea [7]. Previous studies have shown that BRCA-1, P-53 and other tumor suppressor genes are able to increase GADD-45 expression [16-18]. Catalase and GADD-45 are associated with the FOXO pathway; however, these two genes perform different functions of detoxification and DNA repair, respectively. In our study, PhIP treatment increased the expression of BRCA-1 indicating that oxidative stress was induced by PhIP (also confirmed by the DCF assay); curcumin co-treatment reduced the oxidative stress allowing the expression of BRCA-1 to return towards basal levels. Studies have shown that BRCA-1 regulates Nrf2dependent antioxidant signaling by physically interacting with Nrf2 and promoting its stability and activation [19]. Since curcumin inhibits both PhIP-induced ROS production and DNA adduct formation, this agent ultimately reduces DNA-DSB. In addition, curcumin might improve DNA repair mechanisms, and together these responses reduce the possibility of DNA mutations. Such multiple mechanisms of action of curcumin in cancer cells has been documented previously [20]. Our results also indicate that curcumin modulates PhIP-induced effects through the regulation of multiple cell signaling pathways including antioxidant, DNA repair, tumor suppressor pathways (p16) to minimize the damage caused by the food carcinogen PhIP [7].

\section{Acknowledgements}

This work was supported by the Department of Defense, U.S. Army Medical Research and Material Command (W81XWH-10-1-1042), and National Institute of Health, Research Infrastructure in Minority Institution Grant (2P20MD001085-08). Thanks to Dr. Darren Browning and Dr. Wendy B. Bollag of Georgia Regents University, Augusta, Georgia for their support for training and critical comments.

\section{References}

1. Lauber SN, Gooderham NJ (2007) The cooked meat derived genotoxic carcinogen 2-amino-3-methylimidazo[4,5-b]pyridine has potent hormone-like activity: mechanistic support for a role in breast cancer. Cancer Res 67: 9597-9602.

2. Tang D, Liu JJ, Rundle A, Neslund-Dudas C, Savera AT, et al. (2007) Grilled meat consumption and PhIP-DNA adducts in prostate carcinogenesis. Cancer Epidemiol Biomarkers Prev 16: 803-808.

3. Morgenthaler PM, Holzhäuser D (1995) Analysis of mutations induced by 2-amino-1-methyl-6-phenylimidazo[4,5-b]pyridine (PhIP) in human lymphoblastoid cells. Carcinogenesis 16: 713-718.

4. Gooderham NJ, Zhu H, Lauber S, Boyce A, Creton S (2002) Molecular and genetic toxicology of 2-amino-1-methyl-6-phenylimidazo[4,5b]pyridine (PhIP). Mutat Res 506-507: 91-9.

5. Pal D, Banerjee S, Ghosh AK (2012) Dietary-induced cancer prevention: An expanding research arena of emerging diet related to healthcare system. J Adv Pharm Technol Res 3: 16-24.

6. Wilken R, Veena MS, Wang MB, Srivatsan ES (2011) Curcumin: A review of anti-cancer properties and therapeutic activity in head and neck squamous cell carcinoma. Mol Cancer 10: 12.

7. Jain A, Samykutty A, Jackson C, Browning D, Bollag WB, et al. (2015) Curcumin inhibits PhIP induced cytotoxicity in breast epithelial cells through multiple molecular targets. Cancer Lett 365: 122-131.

8. Takahashi S, Tamano S, Hirose M, Kimoto N, Ikeda Y, et al. (1998) Immunohistochemical demonstration of carcinogen-DNA adducts in tissues of rats given 2-amino-1-methyl-6-phenylimidazo [4,5-b]pyridine (PhIP): Detection in Parafilm-embaded sections and tissue distribution. Cancer Res 58: 4307-4313.

9. Targeting Breast Cancer. In: Singh SR, Mishra MK (eds.) Signaling Gene Regulation and Cancer. Nova Science Publishers Inc., pp. 199-222.

10. Redig AJ, McAllister SS (2013) Breast cancer as a systemic disease: a view of metastasis. J Intern Med 274: 113-126.

11. Butler LM, Sinha R, Millikan RC, Martin CF, Newman B, et al. (2003) Heterocyclic amines, meat intake, and association with colon cancer in a population-based study. Am J Epidemiol 157: 434-445. 
Citation: Jain A (2015) Curcumin Inhibit PhIP-Induced Carcinogenicity by Regulating Expression of Nrf2 and FOXO Targets, and BRCA-1 and P16 Expression in Breast Epithelial Cells. J Carcinog Mutagen 6: 236. doi:10.4172/2157-2518.1000236

Page 4 of 4

12. Bendaly J, Metry KJ, Doll MA, Jiang G, States JC, et al. (2009) Role of human CYP1A1 and NAT2 in 2-amino-1-methyl-6-phenylimidazo[4,5b]pyridine-induced mutagenicity and DNA adducts. Xenobiotica 39: 399-406.

13. Nogueira V, Hay N (2013) Molecular pathways: reactive oxygen species homeostasis in cancer cells and implications for cancer therapy. Clin Cancer Res 19: 4309-4314.

14. Waris G, Ahsan H (2006) Reactive oxygen species: role in the development of cancer and various chronic conditions. J Carcinog 5: 14.

15. Sato K, Akaike T, Kojima Y, Ando M, Nagao M, et al. (1992) Evidence of direct generation of oxygen free radicals from heterocyclic amines by $\mathrm{NADPH} /$ cytochrome P-450 reductase in vitro. Jpn J Cancer Res 83: 1204-1209.
16. Zhan Q (2005) Gadd45a, a p53- and BRCA1-regulated stress protein, in cellular response to DNA damage. Mutat Res 569: 133-143.

17. Salvador JM, Brown-Clay JD, Fornace AJ Jr (2013) Gadd45 in stress signaling, cell cycle control, and apoptosis. Adv Exp Med Biol 793: 1-19.

18. Starita LM, Parvin JD (2003) The multiple nuclear functions of BRCA1: transcription, ubiquitination and DNA repair. Curr Opin Cell Biol 15: 345-350.

19. Gorrini C, Baniasadi PS, Harris IS, Silvester J, Inoue S, et al. (2013) BRCA1 interacts with Nrf2 to regulate antioxidant signaling and cell survival. J Exp Med 210: 1529-1544.

20. Ravindran J, Prasad S, Aggarwal BB (2009) Curcumin and cancer cells: how many ways can curry kill tumor cells selectively? AAPS J 11: 495-510 